\title{
The competences of the editor- in-chief of a scientific journal: gaps and trends
}

\author{
Ilda Fontes \\ FGV EAESP Pesquisa e Publicacoes, \\ Fundacao Getulio Vargas Escola de Administracao de Empresas de Sao Paulo, \\ Sao Paulo, Brazil, and \\ Letícia Fantinato Menegon \\ Administração Geral e Recursos Humanos, \\ Fundacao Getulio Vargas Escola de Administracao de Empresas de Sao Paulo, \\ Sao Paulo, Brazil and \\ Escola Superior de Propaganda e Marketing, Sao Paulo, Brazil
}

\begin{abstract}
Purpose - Considering the centrality of the editor-in-chief in the scientific editorial process, this research aimed to investigate what are (if any) the gaps in the current competencies and the future competencies of this professional, according to the evolution of the journals business model.

Design/methodology/approach - The qualitative research method was used, seeking a deeper understanding of the studied group and their professional skills in a practical way. The epistemological approach of pragmatism was adopted, and the semi-structured interview technique was used with a sample of 29 interviews.

Findings - The survey results revealed that the editor-in-chief learns his métier on a daily basis, on-the-job, as a result of a lack of prior preparation, due to the absence of structured training of these professionals. The study showed a change in the competencies of the editor-in-chief, but influenced beyond the scientific business model, involving a broader contemporary scenario of high complexity. Finally, it also contributes by highlighting important skills trends for the editor-in-chief.

Practical implications - It is expected that the results of this research will contribute to institutionalize training and skills development programs for the editor-in-chief and, consequently, for professionalization for the editor-in-chief.

Originality/value - This study deals, for the first time, specifically with the editor-in-chief's skills, where other studies focus on role, functions and responsibilities.

Keywords Editor-in-chief's skills, Individual skills, Scientific journal, Professionalization

Paper type Research paper

\section{Introduction}

Since the late 1990s, there has been a significant increase in the number of journals in the field of Administration, probably driven by the growth in the number of graduate programs and the pressure to publish research results. For instance, between 2000 and 2019, the number of business and management journals held on the Scopus database increased by $224 \%$ (from 654 to 1,463), while on the Web of Science database there were $332 \%$ more in the same period (from 114 to 378). It is clear, however, that the management of journals has not accompanied this growth in numbers.
\end{abstract}

(C) Ilda Fontes and Letícia Fantinato Menegon. Published in Revista de Gestão. Published by Emerald Publishing Limited. This article is published under the Creative Commons Attribution (CC BY 4.0) licence. Anyone may reproduce, distribute, translate and create derivative works of this article (for both commercial and non-commercial purposes), subject to full attribution to the original publication and authors. The full terms of this licence may be seen at $\mathrm{http} / / / \mathrm{creativecommons.org/licences/by/4.0/legalcode}$

The expenses of carrying out the research and producing the article were subsidized by the authors; there were no other sources of funding.

Competences: gaps and trends

Received 14 April 2021

Revised 9 July 2021 19 August 2021

Accepted 27 August 2021 
REGE 29,2

About $86 \%$ of Brazilian journals in the Administration field are published by Higher Education Institutions (HEIs) (Sandes-Guimarães \& Diniz, 2014), which appoint a faculty member as editor-in-chief, someone who is an active and highly representative researcher in the academic community and whose scientific editing activities are simultaneous to their research and teaching tasks. However, such a researcher does not generally have support in terms of human and technological resources to carry out this new task, and editorial roles (editor, reviewer and publisher) overlap. This scenario is different abroad, where most journals are part of research associations or large publishers (Sharma, 2016).

Added to this scenario are the profound changes in the world of scientific journals, mainly due to the Internet and technological development, which have a substantial impact on their business models, structures and processes in general (Abadal, 2020).

The globalization process has also required journals to leave their comfort zone. They are trying to attract foreign readers, authors, reviewers and editors, and rethink the infrastructure (staffing and staff training, for example) they require for this new business environment (Diniz, 2013, 2017).

In this scenario, and considering that the editor-in-chief occupies a prominent role in the scientific editing process, the primary purpose of this research is to identify the gaps in the current and future skills this professional needs and examine the changes that scientific journals are undergoing in their business models.

This study is particularly relevant because it opens research into the editor-in-chief's competences in the field of Administration and fosters debate on this topic, which will have a consequent impact on professionalization in scientific editing.

The literature review presents the key concepts that provide data for achieving the research objective: the role of editor-in-chief, the competences required and the organizational business model of journals. Methodological procedures were based on the qualitative research method, using semi-structured interviews to explore and increase our knowledge of the professional skills of the editors-in-chief of scientific journals. We conducted 29 interviews that were analyzed according to the precepts of Bardin (2016). Finally, we describe and discuss the results per the categories we identified and analyzed according to the research problem.

\section{The role of editor-in-chief of a scientific journal}

Being a recognized researcher in academia, a representative of the state-of-the-art in this area of expertise is an indispensable condition for assuming the role of editor-in-chief in Brazil. However, when someone assumes this position, they generally have no professional experience in the field of scientific editing. Their formation in the role, therefore, occurs empirically, as self-learning and learning on-the-job, with training support offered by organizations linked to the publishing area, such as the Brazilian Association of Scientific Editors (ABEC), Scientific Electronic Library Online (SciELO), and other Brazilian and international organizations (Packer, 2014).

The National Association of Postgraduation and Research in Administration (ANPAD, 2017) lists the editor-in-chief's responsibilities, which are based on the criteria of the Committee on Publication Ethics (COPE, 2011), and corroborates its central role in the editorial process of scientific certification, which is also in line with the São Paulo Research Foundation (FAPESP, 2014).

Targino and Garcia (2008) also highlight the priority requirement of being an active and leading researcher in their field of expertise. The authors talk about learning the métier through practical experience and indicate that it takes eight years to train an editor. They draw attention to the practical difficulties of accumulating both editorial and teaching activities; there is no remuneration, professionalization or infrastructure, especially on the part of the HEIs in which most Brazilian periodicals are concentrated. 
Adding to these perspectives, Sharma (2016) discusses the role and responsibilities of the editor-in-chief of journals in Administration, drawing inspiration from the ten managerial roles presented by H. Mintzberg in The Nature of Managerial Work. He organizes them into interpersonal (representative, leader and connecting element), informational (monitor, disseminator and spokesperson) and decision making (entrepreneur, conflict solver, resource manager and negotiator).

These researchers do not discuss the editor-in-chief's competences per se but rather their responsibilities and functions, their role in the scientific journal. Outside the area of Administration, few existing studies present the competences of other actors in the scientific editing process, such as the scientific editor (Galipeau et al., 2016; Moher et al., 2017). In order to assume these responsibilities as editor-in-chief, however, it is essential to invest in developing their skills, as commonly occurs in the professional sphere.

\section{The concept of competence}

In this section, the concept of competence is dealt with in a comprehensive way, considering the scarcity of studies on the subject of editor-in-chief.

Recognized as one of the precursors of the concept of competence, Katz (1974) researched the administrative skills required for developing future professionals and defended the development of skills through practice. He differentiates three types of skills that managers must have: technical, human and conceptual (Katz, 1974).

In the 1990s, however, the concept of competence gained space in publications in the area of Administration (Sant'Anna, 2002). This was a period marked by major changes in the labor market and how firms and works were organized. As a result, the organizational structure changed profoundly and became a system of networks, with a more horizontal hierarchy, which was a break from the old hierarchical organizational structure.

In this changing scenario, Dutra (2005) stressed a highly relevant innovation in the company-individual relationship and established a new paradigm for mutual development, which benefited both the organization and the individual. Competence presupposes knowing how to mobilize knowledge and skills and respond within the context in which the organization operates, thereby adding value (Dutra, 2005; Fleury \& Fleury, 2001).

Similarly, Sant'Anna (2002) presented the concept of competence "as the result of the combination of multiple types of knowledge - knowing how to do, to act, and to be - that can be employed by individuals for successfully providing responses to the challenges arising from the restructuring and production modernization processes that are in vogue" (p. 43).

From another perspective, Boyatzis, Goleman, and Rhee (2000) addressed emotional competences for achieving a more effective performance. They indicated an emotional intelligence model of the individual, based on "the competences that allow a person to demonstrate the intelligent use of their emotions in managing and working with others in order to be effective at work" (p. 343). They propose five groups of emotional intelligence: selfawareness, self-regulation, motivation, empathy and social skills.

Complementing this discussion, Boyatzis and Saatcioglu (2008) classify three main groups of competence: "(1) cognitive intelligence, such as systems thinking; (2) emotional intelligence, or intrapersonal skills, such as adaptability; and (3) social intelligence, or interpersonal skills, such as networking" (p.93). They add that knowledge and competence are not enough, as top performance is only going to happen if the individual so wishes, which presupposes attention to individual "motivation activators."

In our study, in line with the epistemological perspective of Zarifian (2001) and Le Boterf (2003), who adopted a more interpretive and less rational approach, it is assumed that competence is essentially a combination of formal education and practical daily experience in 
REGE

29,2

\section{2}

a highly complex context, which demands that this knowledge be put into use in new and unusual situations, thus implying a large capacity for adapting to changes and for relearning.

Despite the absence of previous studies on the competences of the editors-in-chief of journals, which indicates this research's originality and pioneering nature, we sought to investigate these competences under the evolution of the journal's business model, as discussed below.

\section{The organizational business model of journals}

From a general perspective, a business model is an essential tool for designing processes, tasks and the various communication networks needed when constructing an information system to support the company's daily work. According to Stähler (2002), it has four pillars: the value proposition for customers and partners, the product and service offered, the value architecture and revenue models.

Sandes-Guimarães and Diniz (2014) consider Stähler's (2002) perspective to be closer to the model of scientific journals and identify authors, readers/libraries, and reviewers as clients and partners. In a study involving Brazilian journals in the Administration field, these authors draw attention to the fact that the value architecture of a scientific journal is directly related to the diligence of the peer review and manuscript selection processes and to the administrative management of the journal, which accounts for its highest costs. These researchers propose a business model for journals based on three aspects: scientific management (article assessment and selection), administrative management (editorial production, financial, marketing, people and others) and the financing model (sponsor, subscriptions and federal development agencies).

Haynes (2012), on the other hand, presents a business model with a focus on how the journal's revenue is generated, highlighting as sources of it the readers (subscription model), the authors (publication fee), sponsors and advertising.

In line with Sandes-Guimarães \& Diniz (2014), our research adopts the perspective of Stähler (2002) and considers the possibility of framing the main aspects of the scientific journal as being an enterprise or a business and, in this sense, identifies those influences that have an impact on the editor's competences.

\section{Methodology}

Since the editor-in-chief of a journal plays a central role in the scientific editing process, in the beginning, our study focused on identifying any possible gaps in current competences, and the future competences required of the professional in question, according to our understanding of the current and future business model of scientific journals (Fontes, 2021). As a result, we outlined the possibility of contributing to the debate on the professionalization of scientific journals, including definitions and innovations in their business model.

We believe that qualitative research was the most suitable method for increasing and exploring the existing knowledge about editors-in-chief of scientific journals and their professional skills (Creswell, 2007; Gil, 2008). Therefore, we adopted a theoretical and pragmatic lens (Dewey, 2007), whose perspective is justified by our empirical investigation, focusing on the practice of the editor-in-chief's métier.

Concerning our investigation strategy, this study adopted a general-purpose, descriptive method type of research, whose primary focus is "a description of the characteristics of a certain population or phenomenon" (Gil, 2008, p. 28).

The sample consisted of interviewees selected for convenience (Creswell, 2007), all recognized in academic Administration circles for their extensive knowledge. Based on the 
ranking of Qualis/Capes periodicals in the Public and Business Administration, Accounting and Tourism area for the 2013-2016 period, involving strata A1 to B4, we started with A1 and selected just Administration journals, to seek wider geographic diversity, then A2, and so on. We contacted editors by email, aiming at obtaining 30 positive responses. We contacted 47 journals and completed 31 interviews, 29 of which were considered for analysis; they represent three continents, with a preponderance of 20 participants $(69 \%)$ from Latin America, as Table 1 shows. It also shows the distribution of journals between strata A (15 interviewees; $52 \%$ ) and B (13 interviewees; $45 \%$ ) of Qualis, and one journal that is not classified by Qualis (3\%).

In order to achieve the proposed objective, we used semi-structured interviews. We looked for a description of the editor-in-chief's current competences and the trends of these competences, under the evolution of journals' business model (Fontes, 2021). The interview script comprised five open questions about current and future competences and business models and a final question of general considerations. Test interviews were carried out with three editors-in-chief, which modified the interview script that was later validated.

Data were collected in September and October 2020 via interviews, 27 using the Zoom platform, one using Jitsi Meet, and another using WhatsApp. The interviews were recorded with the consent of the participants and later transcribed to facilitate categorization and analysis of the research results. We applied the precepts of Bardin (2016), choosing the taxonomy of the data collected for organizing the content analysis process. From a cursory reading of the transcribed interviews, we identified the elements that correspond to the research objectives, namely, (1) What gaps are there (if any) in the current competences? and (2) In the evolution of the business model of periodicals, what future skills does the function of editor-in-chief of a scientific journal require?

Given the significant volume of events collected in the 29 interviews, we identified the need to group them to organize the focal points for analysis. In this sense, categorization, which is "an operation for classifying the constituent elements of a set by differentiation, and then by regrouping according to gender (analogy) with previously defined criteria" (Bardin, 2016, p. 147) was carried out a posteriori. Thus, in the first phase of the categorization, we decided to divide the inventory into two categories, following the research themes that had been defined in the semi-structured interviews:

(1) Category 1: Current competences of the editor-in-chief.

(2) Category 2: Future competences of the editor-in-chief.

This categorization was essential for selecting events related directly to the research question. Since 157 of the elements extracted from the transcribed interviews were identified as being in Category 1 and 55 in Category 2 in the inventory stage, we regrouped each of them based on Bardin's (2016) quality principles for good categories. In this regrouping, in line with the literature review of this research, we looked for coherence with the narratives of the editors-in-chief, which resulted in the following subcategories:

\begin{tabular}{lcccc}
\hline Geographic region & A1-A2 & B1-B4 & Without Qualis & \% by region \\
\hline Latin America & 9 & 11 & - & $69 \%$ \\
Europe & 4 & 1 & 1 & $21 \%$ \\
North America & 2 & - & - & $7 \%$ \\
Asia & - & 1 & - & $3 \%$ \\
Total & 15 & 13 & 1 & $100 \%$
\end{tabular}

Competences: gaps and trends 
REGE

29,2

204
(1) Competence as a researcher (current/future).

(2) Emotional competence (current/future).

(3) Competence in scientific editing (current/future).

(4) Social competence (current/future).

(5) Management competence (current/future).

(6) Technical competence (current/future).

\section{Results}

The research results are analyzed below and aligned with the six subcategories of current and future competences.

\section{Category 1: Current competences of the editor-in-chief}

The editor-in-chief's current competences category was classified in the content analysis into the six subcategories indicated in the previous section.

The first of them, current competence as a researcher, brings together events that concern the skills of the editor-in-chief in the academic world as a scholar of a particular line of research. This involves their production in terms of conducting research and publishing research results, their image and reputation as a researcher, their mastery of the field of study and their knowledge of the field. These events were identified in the narratives of most of the interviewees, as two of them particularly show:

I think that an editor-in-chief ought to have had something published (...) preferably in the topranked journals in the area, so they are accepted by the community as someone who can direct this journal. And for this, I think the editor-in-chief needs to have a history of publications (Foreign editorin-chief, Qualis A1.)

It's obvious that the editor has to have credibility with regard to the traditional part; they have to be a researcher. They have to have achieved something. They have to be someone who's credible. (Editorin-chief from Brazil, Qualis B1.)

These comments point out that the researcher's reputation is essential for them to assume the position of editor-in-chief of a journal. It ensures that the community accepts them and that they attract the most qualified researchers in academia to their journal, which corroborates the literature discussed in this paper (Anpad, 2017; Baskin, 2017; COPE, 2011; FAPESP, 2014; Sandes-Guimarães \& Diniz, 2014; Targino \& Garcia, 2008).

Another competence necessary in the appointment of editors-in-chief is their mastery in their research area and the importance of having a sufficiently broad view of the field, so they have the ability to prejudge manuscripts:

One of the main success factors for being the editor of a journal (...) is that they need (...) to appreciate, to understand the language of the different disciplines so that they can make decisions as to whether an article fits the journal's mission. (Foreign editor-in-chief, Qualis A1.)

Knowledge of the area is very important (...). Why am I saying this? Because when we talk about publishing in a journal, each article that is published must make a well-articulated academic contribution. You must make a contribution. (Foreign editor-in-chief, Qualis B1.)

In these comments, the editors-in-chief indicate how essential it is for them to be clear about the impact of their knowledge on the journal, the public and the community in general. These extracts also set out the competences required for superior performance, based on mobilizing know-how, knowing how to act (Sant'Anna, 2002; Fleury \& Fleury, 2001). 
The second subcategory, current emotional competence, has to do with intrapersonal skills, that is, the editor-in-chiefs ability to understand their own emotions and other people's, and their competence in managing them in the most effective way for achieving their purposes (Boyatzis et al., 2000; Boyatzis \& Saatcioglu, 2008). This is clear in the following narratives:

As the editor of a journal you have to have a certain degree of integrity. You can't be easily influenced. If someone tries to influence you in some way or another, you can't be over-sensitive: with most of the papers you'll have to reject them. If you're too soft (. . .) you probably perceive having to try and read and react to so many papers as a burden. (Foreign editor-in-chief, Qualis A1.)

But you also have to be humble and respect the authors who submit their articles. (Foreign editor-inchief, Qualis A2.)

Given the concern with impartiality in decision making, these words warn of the need for selfknowledge, the importance of equilibrium and managing emotions, since the editor-in-chief occupies a position of micro-power.

In another statement, the degree of responsibility required emerges in relation to the impact of editorial content on forming the opinions of the community and readers in general:

I think we have to have a high level of responsibility with regard to what we do, what we research, what we publish, what we write, at the risk of influencing thousands of people without knowing, and without being very aware of this. (Editor-in-chief from Brazil, Qualis B4.)

In the third subcategory, competence in current scientific publishing, we grouped events related to the scientific certification process, knowledge and a vision of the area of scientific publishing, skills in scientific production and dissemination (Sandes-Guimarães \& Diniz, 2014).

One of the statements takes a different view, in the sense of indicating that something over and above experience as an author and reviewer is needed in order to be a competent editorin-chief:

I thought I could be an editor, but I had no idea... You've already been a reviewer and an author and you figure you could be an editor. And I was really ignorant. I was lucky because I said: "I need to find out more about this business", and so I tried to get to know. (. . .)I saw that there was ABEC, and I went right away to an ABEC congress. (...) I did that course. (. . .) I was almost desperate, because you can't assimilate even $10 \%$ of all that business at one time (...) but I kept after it. (Editor-in-chief from Brazil, Qualis A2.)

This declaration indicates a concern with understanding how the scientific editing area works and clashes with other interviewees who believe that being a reviewer and an author means one has sufficient experience to be an editor-in-chief. However, this is also in line with what other editors say, such as:

So, in a sense I was not totally new to the work. Very few editors-in-chief are new to the work. They've normally been an associate editor of this or that journal. (. . .) So, I think that's a very typical route. (Foreign editor-in-chief, Qualis A1.)

Before becoming an editor of a journal of a particular level, I think you have to have had experience of editing other journals of a good level. (. . .) So, you have to have the background. (Editor-in-chief from Brazil, Qualis A2.)

In these reports and others we collected from the interviews, it is clear that, at an international level, previous experience in editing journals is relevant. Therefore, we can deduce that experience as an author and reviewer does not lead to sufficient skills for assuming the position of editor-in-chief.

Another skill pointed out by the participants was a certain rapport with the editorial area. Although the primary function of the editor-in-chief is doing research and pursuing a career

Competences: gaps and trends 
REGE 29,2

in teaching, they must follow developments in the editorial area because innovations naturally have an impact on the development and projection of the journal, given its ability, or otherwise, to keep up with changes in publishing. In the words of an editor-in-chief:

I think that increasingly you also have to have greater knowledge of the scientific production market. I don't know if we can say that the scientific production market, or the dissemination market, perhaps (. . .) like preprints, open data, and open science. I also think that a very big change is happening in the journal market. (Editor-in-chief from Brazil, Qualis B1.)

It is also interesting to note that in the various places around the world where the interviewees are, there is no structured professional training for developing the competences of editorsin-chief:

Well, [the publisher] told me to make the journal work and there was a tutorial for the ScholarOne system. (Foreign editor-in-chief, Qualis A1.)

I learned by being involved in the journal. I'd not had any training as an editor before taking it over (Editor-in-chief from Brazil, Qualis A2.)

The current social competence subcategory aggregates elements relevant to the interpersonal skills required of editors-in-chief, such as having a good relationship network and being competent in mobilizing it because it is essential to attract authors, reviewers and editors recognized by the academic community. In addition to being directly linked to the editor-in-chief's reputation, these are competences that impact their ability to attract the most qualified researchers to contribute to their journal. In the words of an interviewee:

You have to have a good relationship with a series of people, good academic relationships, I mean, a good reputation. It's no use me wanting now to put in the ship, in the team, a bunch of good people if in the past I was incompetent in my interaction with these people. (Editor-in-chief from Brazil, Qualis A2.)

Depending on my credibility and depending on my network, I'm going to receive good papers. (Foreign editor-in-chief, Qualis B1.)

Looking after relationship networks is similar in journals around the world. All editors-in-chief point to the importance of having a solid relationship network, with people who can effectively collaborate with the journal as either an author, reviewer, or associate or guest editor.

What also stands out are reports about the editor-in-chief having leadership skills, in the sense of attracting and influencing people in the community, based on their knowledge and vision of the field of study:

So I think it's a leadership function of the editor-in-chief (. . .) it's a function in which you have to hug a lot of people. (Foreign editor-in-chief, Qualis A1.)

The editor-in-chief is the leader, because they're really developing and conducting policies. (Foreign editor-in-chief, Qualis B1.)

Events related to management skills are grouped in current managerial competence (Moura \& Bittencourt, 2006; Sant'Anna, 2002; Targino \& Garcia, 2008). It is interesting to note that the reports about managerial competence raise very different concerns among the editors, as can be seen in:

I think that the editor-in-chief must definitely be an excellent researcher. And so it's obvious that they must have managerial skills because you have to manage an operation. (Foreign editor-in-chief, Qualis A1.)

You also have to decide on directions, and that's not easy, so I think that, classically, the editor needs to have a strategic vision. They have to have a strategic vison on this academic point, on the current 
and future trends of the field in which the journal is positioned. (Editor-in-chief from Brazil, Qualis B1.)

These two reports complement each other to the extent that the managerial skills of the editor-in-chief must ensure that the editing process flows satisfactorily on a day-to-day basis, adding to a strategic plan that thus guarantees the journal progresses.

On the other hand, the following statements denote some different realities of editors-in-chief:

I'd say that the second competence (. . . ) they have to be very competent at organizing because there are a lot of things at the same time. I mean, you have to have an entry flow, a publication flow, a backlog. (. . .) I mean you have to have the skill to manage the journal over and above the question of the subject itself, which is very important. (Editor-in-chief from Brazil, Qualis B2.)

Look, the skill lies in time management, because as I said, as editor, I divide my time with my other activities as an academic. So I have to be always thinking about how to manage my time so the activities of the journal don't fall behind. (Editor-in-chief from Brazil, Qualis B2.)

Differently, therefore, these last two reports denote an overloaded editor-in-chief, with an accumulation of activities in a scenario in which managerial, organization and time management skills are required in order to guarantee their survival and meet the commitments they assumed.

Those events related to technical skills are grouped in the current technical competence subcategory (Fleury \& Fleury, 2001; Katz, 1974). These skills are specific to the scientific publishing area, or to interdependent areas, such as languages (knowledge of English), editorial flow management systems, graphic design and others. These can be identified in the following statement:

Another competence I think is essential is the ability to handle the system operationally. It also seems to be a trivial matter, but it's not because the systems change, the operational dimension of the process, the allocation of responsibility, inviting authors, dialogue with the authors, dialogue with the reviewers, and in our case in particular, the whole process of formatting the work, of putting it on the system, of checking it, of changing the number of the pages (...). (Editor-in-chief from Brazil, Qualis B2.)

This extract points out that the ability to deal with the editorial flow management system is essential in the editor-in-chief's routine. For example, the assessment process article involves many steps and many actors. Registering all the steps correctly in the management system is decisive for well managing the process and also contributes to the agility and reliability of the data and the indicators generated by the editorial management system.

\section{Category 2: Future competences of the editor-in-chief}

As we presented in the Methodology section, the same analysis subcategories that were identified for evaluating Category 1 (Current competences of the Editor-in-Chief) are also found in Category 2: Future competences of the Editor-in-Chief.

In the future competence as a researcher subcategory, the interviewees added some new skills, such as a change related to mastering the knowledge required of the editor-in-chief, who will face the challenge of having to reconcile both depth and range:

So if you want to be a good gatekeeper, you need to have sufficient depth, but also enough breadth in your own academic background, in your own academic experience, to be able to maintain this type of journal. (Foreign editor-in-chief, Qualis A1.)

From this report, among others, we can infer that in the future it will no longer be sufficient to have a broad view of the area but also a significant depth of knowledge, which is necessary because of the fragmentation tendency of the various sciences, giving rise to a variety of specialties.
Competences: gaps and trends 
REGE

29,2

\section{8}

In another extract, we notice a concern with the ability of the editor-in-chief to gather the most relevant topics that have an effective research impact, which is also a trend in academia, above all in the Applied Social Sciences:

That you have to find a way of thinking about how you bring topics and conversations to the journal that might have a truly significant impact. (Foreign editor-in-chief; not in Qualis.)

Another skill for the future that the participants indicated is adapting to new situations; that is, flexibility.

If the editor is unable to understand this changing scenario, then perhaps this is the sad part of the future of this editor-in-chief. Because normally, the survivors tend to understand the market, the future, what's happening. (Foreign editor-in-chief, Qualis B1.)

Here, in line with other extracts from the interviews, the participant explains how essential to the future the ability to adapt to changing environments is in order to ensure that the editorin-chief survives, given the intense innovation which the scientific editing area is undergoing, as well as society and the market in general (International Labor Organization, 2017; World Economic Forum, 2020).

In the future emotional competence subcategory, we find a certain continuity with the current scenario because elements like emotional balance, humility, respect, self-knowledge and managing emotions dominated the discourse of those participating in this survey.

Concerning the future social skills of the editor-in-chief subcategory, the reports denote concern with the skills needed for organizing a community in the search for collective collaboration, development and robustness in the area:

I think that more and more they're also going to need to be able to collaborate with other journals because everybody keeps themselves to themselves; each journal within themselves; so (. . . Looking inwards, so they need to see what may happen in the future in this direction. (Editor-in-chief from Brazil, Qualis A2.)

Editors need more social capital with those who coordinate the area. They need to influence them more actively, or make them perceive what our journals are useful for. Of course, they must also havea vision for their own journal, what it means, and what audience it serves (...). How do editors talk to each other? Do they acknowledge one another in the Administration area? As far as I know, they don't talk to each other so far, they don't acknowledge one another. (Editor-in-chief from Brazil, Qualis B2.)

In addition to future leadership skills for the editor-in-chief as an articulator or influencer of the coordinators, and complementing the current skills needed, these words underline the importance of social competence and indicate the gap in the interaction between editors in the Administration area. They also indicate a concern of the editors-in-chief not only for close collaboration on the journal's day-to-day activities but also for strengthening the academic community itself.

Still dealing with the skills required as a leader, in the following extract, the participant points out the privileged access editors-in-chief have to the country's scientific production, which provides them with special knowledge and with the possibility of playing a leading role in the development of research:

And another thing I'm thinking of is that in the future, as editor of a journal, we need a show of strong leadership (. . . ) since we have a more extensive understanding of the future of the field, it's better that the editors demonstrate strong leadership and try to show people that this is an area we need [more research in] (Foreign editor-in-chief, Qualis B1.)

In this report, like so many others, it is evident that the editor-in-chief is already able to assume his/her role as a leader in carrying out research, but he/she has not had the room to explore this environment, which he/she hopes will happen in the future. 
In the future technical competence subcategory, the participants' statements focus on skills already existing and future new forms of communication and information technology, and its development, with direct implications for the world of journals:

In other words, there's going to be no way of avoiding it. The editor-in-chief is going to have good knowledge of technology tools, because this whole area, this prospect of open science, open data, all this involves technology tools. So they're going to have to understand that. And understand social networks. (Editor-in-chief from Brazil, Qualis A2.)

It is evident from these words that the editor-in-chief has no alternative but to learn how to deal with new technologies because innovations in the editorial area (open science and open data) demand this knowledge. In addition, they will need to deal with social media, which are becoming ever more substantial, as an alternative way of disseminating articles because of the facility to interact with the digital means of publishing:

Increasing our relevance, our impact, and for this it's essential, for example, to learn how to communicate via social network. So, we created a LinkedIn page, I updated Facebook, Twitter, how to talk to the authors (...) so, I think that this competence for looking at different forms of communicating science (...) is going to be fundamental, even for the role of editor. (Editor-in-chief from Brazil, Qualis B1).

This testimony indicates that editors are not only attentive to innovations and new professional demands in the editorial area but also adapting to new scenarios and exploring new resources in favor of the journal and, naturally, of academic-scientific development.

In the future managerial competence subcategory, elements that refer to skills related to managing and raising financial resources were mentioned. The latter, especially, became very relevant in the discourse of the interviewees:

Well, I think this competence should be the same, except that perhaps there's more pressure on the editor-in-chief to be a businessperson in the sense of trying to find ways to generate revenue (Foreign editor-in-chief, Qualis A1)

Furthermore, in a situation in which the editor-in-chief currently has no editorial team to help them in their daily work in the journal, their expectation for the future is to be able to have such a team and improve the article assessment process, which signals aspects of their professionalization:

Then it's easier, because you can do the desk review, for example. You can get the article and before you pass it on to a colleague, you can have a prior reading of it and actually carry out a qualified review of it before sending it to a colleague. (...) That's how you're able to share tasks. (Editor-inchief from Brazil, Qualis B2.)

I would only add that I expect the editing of journals to become more professional (. . .) because it's not a professionalized task. It's a job that editors take on because they take on. (. . .) I expect that (. . .) editors will look at that as a task for which they're responsible (...) they have the prospect of progressing and improving in relation to the next, and so on and so forth. (Editor-in-chief from Brazil, Qualis B2.)

In the future scientific editing subcategory, the highlight is the report on a more accurate understanding of the business of journals and their impact on citations and operating efficiency:

It's also the case that I think that journal editors should become more aware and understand the business aspects of journals. Therefore, if you're a journal that belongs to a company, most of the time as an academic editor you don't worry about the business. (...) It's like managing a plant in some aspects. I think that journal editors need to become more aware and understand a lot more than the operational aspects of managing a journal. (Foreign editor-in-chief, Qualis A1.)

It is evident here that in addition to the skills needed to understand the journal's business model, this demand for competence differs according to the type of publishing institution;

Competences: gaps and trends 
REGE

29,2

\section{0}

whether it is a scientific association, for example, which will only require of the editor-in-chief the competences needed for scientific certification, or it is a commercial publisher, which will then require that the editor-in-chief understands the impact of the selected article on the efficiency of the business itself, that is, in terms of citations, marketing, etc., as discussed by Sharma (2016).

On the other hand, this view clashes with the perception of another editor-in-chief, who perceives the professionalization that a publisher provides to journals as a risk to the editorin-chief's role as we know it today:

Perhaps this business model will dispense with the need for the figure of the editor-in-chief as it is today. Perhaps journals going to publishers implies the suppression of the editor-in-chief as he is today: a professor from the area, someone dedicated (...). I think that with publishers, he'll tend to disappear. The publisher is a professional who goes after good publications, offering reading and subscriptions; there's been a complete change in today's model. So I think that in the end editors like me tend to disappear. (Editor-in-chief from Brazil, Qualis B2.)

From these last two testimonies, we can deduce that their disparate views denote the degree of uncertainty and change in the current scenario of scientific journals worldwide. Moreover, this scenario of uncertainties also signals a highly complex context, which can be abstracted from another point of view present in the statements about restrictions in terms of projecting the editor-in-chief's future competences:

We need to see whether journals are even going to continue to exist. Because if journals disappear in the traditional sense as we know them, then the editor may disappear. The question is, how are we going to maintain this research machine and publish results, then? Who's going to be responsible for this? (Editor-in-chief from Brazil, Qualis A2.)

This last comment reinforces the degree of uncertainty and change in scientific editing, indicating to its various actors that the way in which it is organized and functions are being reconstructed, including its very business model.

\section{Conclusion}

The present study sought to identify possible gaps in the editor-in-chief's competences in relation to the evolution of the business model of scientific journals. This study is important for it introduces an approach to the competences of the editor-in-chief that is relevant for the evolution of the current literature on this topic. Existing literature does not generally address the competences themselves but narratives on aspects such as the editor-in-chief's role, responsibilities and functions (Anpad, 2017; COPE, 2011;FAPESP, 2014; Packer, 2014; Sharma, 2016; Targino \& Garcia, 2008). Our results, however, showed that some of the current competences of editors-in-chief are directly related to these roles and responsibilities. At the same time, the study contributes to the development of these skills in a structured way, with direct gains for this professional's practice and professionalization in scientific publishing.

The testimonies of the editors-in-chief point to a close alignment with theoretical references on competence, to the extent that the editor-in-chief has a robust formal education, in addition to empirically learning from practicing their métier (Le Boterf, 2003; Zarifian, 2001) in a highly complex context, which leads to knowledge being enhanced and mobilized in the search for assertive answers to unusual situations (Boyatzis et al., 2000; Boyatzis \& Saatcioglu, 2008; Dutra, 2005; Fleury \& Fleury, 2001; Katz, 1974; Sant'Anna, 2002).

Considering the result of our qualitative research, we identified a lack of structured training for editors-in-chief, with a consequent lack of development of their skills, and, consequently, they learn their work daily from the mistakes they make and the successes they have. 
Despite the complexity of the current moment and the uncertainties for subsequent years, the research findings revealed seven competences projected for the future:

(1) Intellectual maturity (involving mastery and broad knowledge, a vision for the area, research background and experience in the area).

(2) More in-depth knowledge (given the growing specialties of the Administration area), while having an increasingly broader view of the area.

(3) Leadership, in the sense of attracting and influencing people, which also involves skills in organizing and building communities.

(4) Skills in the new ways of communicating science (social media and others).

(5) Skills in using new technologies.

(6) Flexibility and adaptation to rapidly changing environments.

(7) Understanding of the business of journals (focusing on the impact of citations, the economy and the improved efficiency of the journal).

These competences reflect the influences that come from a broad and highly complex context, since contemporary changes and uncertainties (technological development, demographic changes, dilemmas introduced by open science, among others) have impacts that are still undefined for the future. These influences, therefore, go beyond the evolution of business models for scientific journals.

The structured development of competences for the editor-in-chief demands special attention, as he/she is a genuine professional researcher, who has no intention of pursuing a career in the editorial area. Researchers temporarily assume the position of editor-in-chief, given their well-known knowledge and relevant academic production, and do so to contribute in a particular way and add value to scientific development. A structured training and skill development program for the editor-in-chief needs to consider this unique aspect.

ABEC and COPE have provided a valuable service to editors and the various actors in the Brazilian editorial area, as identified in the comments made by the editors-in-chief. These efforts are complemented by webinars offered by major publishers and service companies to the editorial area. At present, however, there is no structured training program for editors-in-chief.

We believe that these organizations, which are already quite influential in training and guiding scientific editing professionals, and the HEIs that already work with professional qualifications could structure training programs for the editorial area, starting with the editor-in-chief, given their central role as a gatekeeper of science. This training program initiative is essential given the direct gains for the management, performance and efficiency of the journal and the professionalization of the editorial area.

From another perspective, there was a restriction in obtaining more significant knowledge about the business models of journals since the editor-in-chief is not always fully aware of the circumstances under which these are developed. This is particularly true in the case of journals published by large publishers, which are organized to keep the editor-in-chief separate from matters relating to the business model. We suggest, therefore, that investigation of business models should continue, especially with large publishers.

It is also worth remembering that scientific journals are part of the communication and dissemination area of science, which has an impact not only on scientific development but also on the economic development of nations.

Finally, we presume that the originality of this research on the competences required by the editor-in-chief of a journal will raise questions and encourage new studies that will contribute to innovations in the editorial area and its development. We also believe that the
Competences: gaps and trends 
REGE 29,2

competences described in the findings of this research will help develop structured training programs for the editors-in-chief of scientific journals and encourage new studies that will contribute to the professionalization of the editorial area.

\section{References}

Abadal, E. (2020). Un libro para explicar los marcos y los retos de las revistas científicas. In L. da Silveira, \& F.C.C. da Silva (Eds.), Gestão editorial de periódicos científicos [recurso eletrônico]: tendências e boas práticas (pp. 11-16). Florianópolis: BU Publicações/UFSC, Edições do Bosque/ CFH-UFSC. doi: 10.5007/978-65-87206-08-0/0.

Associação Nacional de Pós-Graduação e Pesquisa em Administração (Anpad) (2017). Boas práticas da publicação científica: Um manual para autores, revisores, editores e integrantes de Corpos editoriais. Rio de Janeiro, Disponível em. Available from: http://www.anpad.org.br/diversos/ 2017/2017_Boas_Praticas.pdf.

Bardin, L. (2016). Análise de conteúdo. Edição revista e ampliada, São Paulo, Edições 70 LDA/ Almedina Brasil.

Baskin, D.G. (2017). Journal editors short course: Understanding your editor, reviewers, and authors, Paper Presented at Council of Science Editors 2017 Annual Meeting, 20-21 May 2017, San Diego, California.

Boyatzis, R.E., Goleman, D., \& Rhee, K.S. (2000). Clustering competence in emotional intelligence: Insights from the emotional competence inventory. In R. Bar-On, \& J.D.A. Parker (Eds.), The handbook of emotional intelligence: theory, development, assessment, and application at home, school, and in the workplace (pp. 343-362). San Francisco: Jossey-Bass.

Boyatzis, R.E., \& Saatcioglu, A. (2008). A 20-year view of trying to develop emotional, social and cognitive intelligence competencies in graduate management education. Journal of Management Development, 27(1), 92-108.

Committee on Publication Ethics (COPE) (2011). Code of conduct and best practice guidelines for journal, editors. 2015. Available from: https:/publicationethics.org/files/Code_of_conduct_for_ journal_editors.pdf.

Creswell, J.W. (2007). Projeto de pesquisa. Porto Alegre. Artmed.

Dewey, J. (2007). O desenvolvimento do pragmatismo americano. Scientia Studia, 5(2), 227-243, June. doi: 10.1590/S1678-31662007000200006.

Diniz, E.H. (2013). Editorial. RAE-Revista de Administração de Empresas, 53(2), 123, mar.-abr, doi: 10.1590/S0034-75902013000200001.

Diniz, E.H. (2017). Periódicos brasileiros da área de administração no contexto de internacionalização da produção científica. RAE-Revista de Administração de Empresas, 57(4), 357-364. doi: 10.1590/s0034-759020170406.

Dutra, J.S. (2005). Gestão por Competência. In Seminário "A Gestão de Pessoas no Setor Público". Available from: https://www.youtube.com/watch?v=AOIlrkp5gf0.

Fleury, M.T.L., \& Fleury, A. (2001). Construindo o conceito de competência (pp. 183-196). Curitiba: Edição Especial: RAC-Revista de Administração Contemporânea, doi: 10.1590/S141565552001000500010.

Fontes, I. (2021). Competências do editor-chefe de periódico científico: Gaps e tendências. (Masters dissertation, Fundação Getulio Vargas, Escola de Administração de Empresas de São Paulo). Available from: https://hdl.handle.net/10438/30207.

Fundação de Amparo à Pesquisa do Estado de São Paulo (FAPESP) (2014). Código de boas práticas científicas. São Paulo: FAPESP. Available from: http://www.fapesp.br/boaspraticas/FAPESPCodigo_de_Boas_Praticas_Cientificas_2014.pdf.

Galipeau, J., et al. (2016). A scoping review of competencies for scientific editors of biomedical journals. BMC Medicine, 14, 16, doi: 10.1186/s12916-016-0561-2. 
Gil, A.C. (2008). Métodos e técnicas de pesquisa social, São Paulo: Atlas.

Haynes, J.S. (2012). In R. Campbell, E. Pentz, \& I. Borthwick (Eds.), Development of journal publishing business models and finances. Oxford: Academic and professional publishing, Chandos Publishing/Cambridge: Woodhead Publishing Limited.

International Labor Organization (2017). The future work we want: A global dialogue. Available from: https:/www.ilo.org/wcmsp5/groups/public/—dgreports/—cabinet/documents/publication/ wcms_570282.pdf [August 2017].

Katz, R.L. (1974). Skills of an effective administrator. Harvard Business Review, 52(5), 90-102.

Competences: gaps and trends

Le Boterf, G. (2003). Desenvolvendo a competência dos profissionais (3a. ed). Porto Alegre: Bookman/ Artmed.

Moher, D., et al. (2017). Core competencies for scientific editors of biomedical journals: Consensus statement. BMC Medicine, 15(1), 167, doi: 10.1186/s12916-017-0927-0.

Moura, M.C.C.de, \& Bitencourt, C.C. (2006). A articulação entre estratégia e o desenvolvimento de competências gerenciais. RAE-eletrônica, 5(1), Art. 3. Available from: https://rae.fgv.br/raeeletronica/vol5-num1-2006/articulacao-entre-estrategia-desenvolvimento-competenciasgerenciais.

Packer, A.L. (2014). A eclosão dos periódicos do Brasil e cenários para o seu porvir. Educação e Pesquisa, 40(2), 301-323, doi: 10.1590/S1517-97022014061860.

Sandes-Guimaraes, L.V.D., \& Diniz, E.H. (2014). Gestão de periódicos científicos: Estudo de casos em xrevistas da área de administração. Revista de Administração (São Paulo), 49(3), 449-461, doi: $10.5700 /$ rausp1160.

Sant'Anna, A.S. (2002). Competências individuais requeridas, modernidade organizacional e satisfação no trabalho: uma análise de organizações mineiras sobre a ótica de profissionais da área de administração [Doctoral thesis]. Belo Horizonte: Faculdade de Ciências Econômicas, Universidade Federal de Minas Gerais).

Sharma, P. (2016). The job of a journal editor. Family Business Review, 29(3), 247-255, doi: 10.1177/ 0894486516655901.

Stähler, P. (2002). Business models as a unit of analysis for strategizing. Blog Business Model Innovation, Sept. Retrieved from Patrick Stähler | Business Model Innovation (business-modelinnovation.com).

Targino, M.G., \& Garcia, J.C.R. (2008). O editor e a revista científica: Entre “o feijão e o sonho”. In S.M.S.P. Ferreira, \& M.G. Targino (Eds.), Mais sobre revistas científicas: em foco a gestão. São Paulo: SENAC/Cengage Learning.

World Economic Forum (2020). The future of jobs report 2020. Available from: http://www3.weforum. org/docs/WEF_Future_of_Jobs_2020.pdf.

Zarifian, P. (2001). Objetivo competência: Por uma nova lógica. São Paulo: Atlas.

\section{Corresponding author}

Ilda Fontes can be contacted at: ilda.fontes@fgv.br

Associate Editor: Adriana Marotti de Mello

For instructions on how to order reprints of this article, please visit our website:

www.emeraldgrouppublishing.com/licensing/reprints.htm

Or contact us for further details: permissions@emeraldinsight.com 